\title{
WAGE INEQUALITY AND FAMILY \\ LABOR SUPPLY
}

Chinhui Juhn

Kevin M. Murphy

Working Paper 5459

\section{NATIONAL BUREAU OF ECONOMIC RESEARCH 1050 Massachusetts Avenue \\ Cambridge, MA 02138 \\ February 1996}

\begin{abstract}
We are indebted to Robert Topel, Robert Vishny, and Finis Welch for valuable discussions. We would like to thank seminar participants at University of Chicago and University of Houston for their helpful comments. We also gratefully acknowledge support from the National Science Foundation and the Bradley Foundation. This paper is part of NBER's research program in Labor Studies. Any opinions expressed are those of the authors and not those of the National Bureau of Economic Research.

(C) 1996 by Chinhui Juhn and Kevin M. Murphy. All rights reserved. Short sections of text, not to exceed two paragraphs, may be quoted without explicit permission provided that full credit, including $\odot$ notice, is given to the source.
\end{abstract}




\title{
WAGE INEQUALITY AND FAMILY \\ LABOR SUPPLY
}

\begin{abstract}
Using data from the March CPS and the 1960 Census, this paper describes earnings and employment changes for married couples in different types of households stratified by the husband's hourly wage. While the declines in male employment and earnings have been greatest for low wage men, employment and earnings gains have been largest for wives of middle and high wage men. These findings cast doubt on the notion that married women have increased their labor supply in the recent decades to compensate for the disappointing earnings growth of their husbands. We conclude that own wage effects dominate cross effects between husband and wife in accounting for changes in male and female employment.
\end{abstract}

Chinhui Juhn

Department of Economics

University of Houston

Houston, TX 77204-5882

and NBER
Kevin M. Murphy

Graduate School of Business

University of Chicago

Chicago, IL 60637

and NBER 


\section{Introduction}

In 1969 the average prime age male in the U.S. was employed a little more than 95 percent of the year and earned roughly $\$ 23,000$ per year (in 1982 dollars). His wife, on the other hand, earned approximately $\$ 4,000$ per year and was employed in the labor market only about 39 percent of the year. By 1989 the average prime age male worked slightly less and earned slightly more than in 1969, working about 93 percent of the year and earning $\$ 25,000$. The story for the wives of these men is quite different. By the late 1980s wives of prime age males worked 66 percent of the year and they earned an average of $\$ 9,000$ per year. Hence over the two decades of the 1970 s and 1980 s time worked for married males declined and their earnings increased slightly while the time worked and earnings of their spouses very roughly doubled.

One natural question and the primary question we address in this paper is whether these two phenomena are closely linked. That is, are married men working less today because their wives are working more? Alternatively, have married women increased their time worked in response to the decline in employment and the lackluster earnings growth of their husbands? The aggregate figures cited above would seem to support these arguments.

In this paper, we supplement the aggregate evidence cited above with evidence from the cross section comparing earnings and employment changes for married couples in different types of households stratified by the level of the husband's hourly wage. In doing so we find that compensating changes in husbands' and wives' earnings and time worked seen in the aggregate mask a very different structure at the individual level. We find that while the declines in male employment and earnings have been greatest for low wage men, employment and earnings gains for married women have been highest for the 
wives of middle and high wage men. For example, between 1969 and 1989 the average real annual earnings of married men in the bottom wage quintile decreased by about 29 percent and their employment rate fell 12 percentage points. While the labor market performance of these men have been far worse than average, employment and earnings of their wives grew only 16 percentage points and 66 percent respectively lagging behind those of other women. Given these data the past two decades might be characterized as a period when low wage men worked less while the wives of high wage men worked more.

The findings described above closely parallel those of several other authors (Cancian, Danziger, and Gottschalk (1993), Blackburn and Bloom (1990)) who have recently reported that rising correlation of wife's and husband's earnings is a significant contributing force towards rising inequality of family incomes. While rising inequality is the underlying theme in much of our analysis, we do not explicitly consider here whether women have contributed to inequality (Cancian, Danziger, and Gottschalk) or to what extent the rise in correlation of spouses' earnings accounts for the rise in family earnings inequality (Blackburn and Bloom). Our first goal in this paper to describe in a clear and simple manner the changes in employment and earnings of married men and women. While much of our analysis is descriptive, we view disaggregating the data by the husband's wage percentiles to be a key and innovative approach taken in this paper. Percentiles calculated on the basis of wages, rather than earnings, is likely to be a better measure of the husband's relative earnings potential since it is less subject to temporary employment shocks and business cycle effects. Once the data is organized in this manner, we find close parallel trends towards inequality in male wages, male employment, as well as earnings and employment of their wives.

Our second goal in this paper is to explore to what extent rapid changes in 
spouse's earnings have affected the labor supply of men and women. In addition to the cross sectional evidence, we compare time series changes over a longer time period than is typically studied by using the 1960 Census as well as the March Current Population Surveys. Time series evidence over the three decades, the 1960s, the 1970s and the 1980s, also casts some doubt on a simple story of families substituting husband's and wife's time and earnings. In contrast to the 1970 s and the 1980 s we find that employment of low wage men actually increased during the 1960 s in spite of the fact that earnings growth for their wives was greater in the 1960s than during the later decades. One can conclude from this that female earnings was not the only significant factor determining the pattern of male employment over these three decades. In fact these findings reconfirm our earlier findings (Juhn (1992), Juhn, Murphy and Topel (1991)) that declining wages generated by falling demand for low skilled workers played the major role in the decline of male employment rates in the 1970s and the $1980 \mathrm{~s}$.

Trying to explain the rise in female employment over the past two decades based on the slow growth of husband's earnings is even more difficult. First, employment rates for married women have been rising over the entire 20th century (see for example Smith and Ward (1985)). Since male incomes have been rising over the vast majority of this time period, we are not surprised that the bulk of the increase in female labor supply cannot be explained by changes in husbands' earnings. A more limited but realistic goal may be to see whether the acceleration of the increase in female labor supply in the 1970s and the 1980s (as compared to the 1960s) can be attributed to the slowdown in male earnings growth during the 1970 s and the 1980s. We find that at the aggregate level this story fits the data exceptionally well. Married women's employment increased approximately 11.9 percentage points over the 1960 s as husbands' earnings increased 32 percent and grew at an accelerated pace (rising by 13.3 percentage points per decade in 
the 1970 s and 1980s) as husbands' earnings growth slowed to less than 5 percent per decade. These types of observations may be the basis of the popular view that the increase in women's time in the market was not a matter of choice but a matter of necessity.

Once again however we find that the aggregate evidence hides a much more interesting structure at the individual level. First, the wives of low wage men (those women married to men in the bottom quintile) had fastest employment growth in the 1960 s when their husbands' earnings grew 42 percent. These women actually slowed their entry into the labor market in the 1970 s and the 1980s as their husbands' earnings fell sharply. Just as in the cross sectional comparisons, we find that the biggest slowdowns in earnings growth occurred for low wage men while the biggest acceleration in female participation came from the wives of high wage men. This fact suggests to us that increased market opportunities for women-- particularly for highly skilled women-may have played a greater role than husbands' earnings in fueling the acceleration of female employment in the 1970 s and the 1980 s.

The paper is organized as follows. Section II describes the matched husband and wife data from the CPS and Census which we use to analyze changes in employment and earnings for married couples. In this section we also briefly describe the changes in marriage rates which may have affected our sample. In section III we describe changes in employment and earnings for married men and married women that occurred over the 1970 s and 1980 s for the full sample as well as disaggregated by husband's wage decile. We also explore in a simple way whether compositional changes towards households without children could in any way account for the observed changes in female labor supply. Section IV extends the time period of the analysis using data from the 1960 Census. In section $V$ we attempt to quantify the effects of changes in spouse's earnings 
on employment using a range of cross sectional estimates and use these estimates to reach our conclusions about the potential importance of spouse's earnings in explaining the employment changes observed for married men and women over the 1970 s and 1980s. Our basic conclusion is that cross effects probably do not account for a significant part of the change in employment for either husbands or wives. Section VI concludes.

\section{The Data Set of Married Couples}

This paper is based on data from the Annual Demographic Files on the March Current Population Surveys (CPS) for the survey years 1968-1992. Since most of our calculations are based on annual earnings and weeks worked in the year previous to the survey, our analysis covers the calendar years 1967-1991. We single out three years of comparable labor market activity-- 1969, 1979, and 1989 to study long term changes. To further ensure against possible business cycle effects, we average three years of data centered around these years. Thus the averages we report for 1969, 1979, and 1989 are actually based on the 1968-70, 1978-80, and 1988-90 CPS data. In addition, we use the 1960 decennial Census to examine changes in wife's time worked although lack of data comparability limits our ability to extend our analysis fully to include the 1960 s.

In this paper we focus on a sample of matched husband-wife pairs where neither spouse lived in group quarters, where neither spouse was in school or military service, and where the husband has between 1 to 30 years of potential labor market experience. As a result, the men in our sample range from 18 to approximately 53 years of age. The age range of women in the sample is larger although the average age of women is 
slightly lower. ${ }^{1}$ Our sample sizes are $54,687,64,230$, and 56,950 observations for 1968 $70,1978-80$ and $1988-90$ respectively. In addition, we have 237,294 observations from the 1960 Census.

One concern is that by focusing on a sample of married couples we are looking at a group that is becoming increasingly selected over time. Among men with $1-30$ years of experience the fraction married and living with a spouse declined 19 percentage points from .82 in 1969 to .63 in 1989 . While a permanent decline in the likelihood of being married appears to be more important for the low wage men and delay of first marriage is more a factor for the high wage men, the decline in marriage rates is more or less uniform across the percentile categories. There is some evidence that this uniform decline in marriage rates has lead to an improvement in the quality of the single male population. For example, among single men with 1-30 years of experience the fraction falling into the bottom decile of the overall wage distribution declined from 21.6 percent in 1969 to 15.5 percent 1989 . The effect of declining marriage rates on the average quality of the married population appears to be less significant, however. Among our sample of married men the fraction in the bottom wage decile fell only slightly from 7.5 percent 1969 to 6.9 percent 1989 while the fraction in the top wage decile increased slightly from 10.9 to 12.2 percent over the same time period. These results suggest that our calculations based on the married population should not be seriously affected by such changing selection bias.

After selecting our sample of matched husband-wife pairs we assign to each couple a percentile category based on the husband's wage. To determine the husband's percentile position, we constructed a sample of all men (both married and single) with 1-

\footnotetext{
${ }^{1}$ In previous versions we also attempted to account for cohabitants by matching unrelated males and females living in the same households. Adding cohabitants to the sample did not seriously alter our results.
} 
30 years of potential labor market experience who were not in school or the military. For each year of potential experience, we then ranked individuals based on their percentile position in the hourly wage distribution in each year. One difficulty is that earnings are not observed for men who did not work the entire year. Following a method introduced in previous papers (Juhn (1992), Juhn, Murphy and Topel (1991)), we imputed wages to nonworking men from the wage distribution of those who worked 1-13 weeks while controlling for education level, potential experience, marital status and labor market status of the spouse. We also corrected for measurement error in hourly wages which arises from dividing annual earnings by total annual hours worked by using the distribution of hourly wages reported on survey week data which is available for the outgoing rotation groups for the years 1982-1992. These methods are described in greater detail in the appendix and also in Juhn (1992) and Juhn, Murphy, and Topel (1991).

\section{Changes in Earnings and Employment}

In this section we describe changes in employment and earnings of married men and married women over the period 1969 to 1989 . We begin by documenting the enormous rise in male wage inequality that has been noted in numerous other studies. ${ }^{2}$ As we show in the following figures and tables, however, a trend towards inequality can be seen along other dimensions such as male employment rates and employment and earnings of wives.

Figure 1 presents the change in log hourly wage among the sample of married

\footnotetext{
${ }^{2}$ For a comprehensive analysis of the recent changes in U.S. wage structure see Katz and Murphy (1992). For reviews of the recent literature see Karoly (1990) and Levy and Murnane (1992).
} 
men with 1 to 30 years of potential labor market experience. ${ }^{3}$ Figure 1 tells a now familiar story. While real wages of men in the top wage decile increased 15 percent, the real wages of men in the bottom wage decile declined as much as 29 percent. The decline would be even more dramatic for this bottom wage group if we used 1973 rather than 1969 as the benchmark. Figure 2 illustrates that the employment rate (measured as employed weeks divided by total weeks per year) of the bottom decile also declined dramatically (by 16 percentage points) while the employment rates of the top deciles actually increased slightly. As a result of the fall in both wages and employment, real annual earnings for men in the bottom decile fell about $\$ 2900$ or by about 35 percent.

While employment rates for men have generally declined, employment rates of their wives increased enormously. In the aggregate the employment rate of married women in our sample increased 27 percentage points from 39 percent in 1969 to 66 percent in 1989. Figure 3 compares the average employment rates of women married to men in the ten wage deciles in 1969 and in 1989. Figure 3 shows that employment rates increased among all married women but increased the most among wives of men in the middle and the top wage deciles. This non-neutral increase has led to a dramatic change in the distribution of wife's employment by husband's wage decile. In 1969 (darkly shaded bars) there was a clearly negative relationship between the husband's wage and wife's likelihood of being employed. That is, the higher the husband's wage, the less the wife worked. By 1989 (shown with lightly shaded bars) this relationship had changed with wives of men in the middle of the wage distribution working the most. Changes in annual hours of work shown in Figure 4 tell the same story. Wives of men in the bottom

${ }^{3}$ To calculate the wage changes reported in Figure 1, we averaged log hourly wages of wage and salary workers who did not work in the agricultural sector. Hourly wages are annual earnings divided by the product of weeks worked and usual weekly hours. Annual earnings were deflated by the personal consumption expenditure deflator from the National Income and Product Accounts. 
wage category increased their annual hours worked by roughly 300 hours while the wives of men the middle and the top wage categories increased their hours twice as much, by roughly 600 hours per year.

Table 1 examines the change in wife's average annual hours worked more closely by decomposing the change in average annual hours into changes in three component parts-- the fraction of women who worked at least one week (annual participants), average weeks worked among the annual participants, and hours worked per week among those who worked in any given week. Table 1 suggests that the bulk of the change in total annual hours (close to 50 percent) is due to increases in the fraction of women who worked at least 1 week out of the year. It appears that relatively little of the change is due to women moving from part-time to full-time status. For example, for the sample of married women as a whole, approximately 16 percent $(.043 / .262)$ of the change in annual hours is attributable to the change in hours per week. ${ }^{4}$

In Figure 5 we examine average hourly wages of working wives by husband's wage decile. $^{5}$ In contrast to the negative relationship between wife's time worked and the husband's wage we found in Figure 3 for 1969, we find that wages of spouses have always been positively related. That is, even in 1969 high wage men tended to be married to high wage women. In 1969 , working wives of men in the bottom decile earned

\footnotetext{
${ }^{4}$ Coleman and Pencavel (1993) report in fact that weekly and annual hours among "working women" have declined since 1940. The difference from the results reported here may be due to the fact that they follow a select sample of "working women" who worked last week as well as last year.

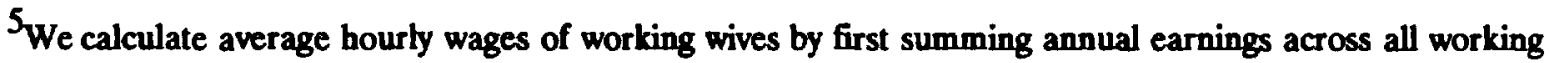
wives and dividing this number by the sum of total annual hours worked by working wives. This is a weeksweighted measure of the hourly wage which would be analogous to the average hourly wage calculated from survey week earnings reported on the May CPS. Smith and Ward (1989) and Goldin (1989) argue that wage growth for women has been understated due to changing composition of working women induced by the entry of women with low levels of experience into the labor market. Our weeks-weighted average wage would downplay the importance of this compositional change by giving greater weight to women with stronger labor market attachment.
} 
approximately $\$ 4.40$ per hour (in 1982 dollars) while working wives of men in the top decile earned approximately $\$ 7.50$ per hour. Since that period, however, the relationship between the husband and the wife's wage has become increasingly more positive as the wives of men in the top decile gained about 38 percent in real wages while wives of the lowest decile men gained about 21 percent. While it is possible that the underlying sorting pattern has changed so that men and women are now more positively sorted than before, it is more likely that these differential wage gains reflect a more general pattern of high skilled women gaining on less skilled women. For example, if we take the same sample of married women and compare across education categories rather than the husband's wage categories, we find that wages of college educated women rose from an average of $\$ 8.50$ in 1969 to $\$ 10.20$ in 1989 (a gain of 20 percent) while wages of high school dropout women increased 2.8 percent and wages of high school graduate women rose 7.9 percent.

Incorporating the changes in both wages and hours worked, Figure 6 describes the change in wife's annual earnings by husband's wage decile. In 1969 wife's annual earnings were essentially constant across husband's wage deciles. While wives of high wage men worked less hours, they were paid more per hour. In contrast, in 1989 there is a very strong positive relationship between husband's wage and wife's earnings. Once again, the largest increases in earnings have occurred for wives of men in the top deciles. Annual earnings of wives in the bottom decile rose approximately $\$ 2300$, an increase of about 63 percent. Annual earnings of wives in the top decile rose $\$ 7700$ an increase of well over 200 percent. By the end of our data, wives of high wage men worked almost as many hours but earned significantly more per hour than wives of low wage men. ${ }^{6}$

\footnotetext{
6 We also investigated to what extent the increase in annual earnings is due to increases in hours worked as opposed to increases in the hourly wage. For the sample of married women as a whole, the rise in annual hours alone accounted for approximately 57 percent of the total change in annual earnings. The increase in hours
} 
While estimation of a structural model incorporating the joint nature of women's marital, work and fertility decisions is beyond the scope of this paper, we can examine to what extent changes in fertility are correlated with changes in wife's labor market participation across these low and high wage households. Column (1) of Table 2 presents changes in the fractions of married women without children over the 1969-89 period. Table 2 illustrates that changes in fertility patterns are correlated with changes in female labor supply across these percentile categories. For example, the fraction of married women without children increased about 7 percentage points for the bottom quintile while the fraction increased almost twice as much (by 13 percentage points) for the top quintile. Given that women with children work significantly less than women without children, it is possible that differing changes in fertility could account for the differential increases in female labor supply across these low and high wage households. In columns (2) and (3) we investigate the role of fertility changes by comparing actual employment changes to employment changes where the composition of women across fertility categories (women without children, women with children aged 1-6, women with children aged 7-18) are fixed. Column (2) reports the actual changes while column (3) reports the composition-fixed changes. ${ }^{7}$ Table 2 shows that the bulk of the total change (.25 out of .27 ) in the aggregate employment rate of married women is attributable to changing employment rates within fertility classes. In addition, the within component appears to be important for both the high and low wage households. Our basic conclusion (at least based upon the simple approach we have taken here) is that changes

appears to be somewhat more important for women in the low and middle percentile categories, accounting for approximately $2 / 3$ of the change in earnings.

7 Since family composition variables such as the presence of children are defined on the basis of the survey week, we also define our employment status based on the survey week and report the fraction who are employed during the survey week. The changes in employment rates reported here therefore will differ slightly from the changes based on weeks worked numbers which are reported in the rest of the paper. 
in employment across all categories of women rather than changes in fertility patterns play the predominant role in accounting for the aggregate increase in female labor supply as well as the differences across these households. Figure 7 emphasizes this point. Figure 7 illustrates average employment rates of women with children 6 years old or less in 1969 and again in 1989 . While the levels of employment differ, both the changes and the observable pattern across the percentile categories are very similar to those exhibited in Figure 3. Among women with young children, the employment rate increased 28 percentage points from .26 in 1969 to .54 in 1989 (the corresponding change for the whole sample of women was an increase of 27 percentage points). As was the case in Figure 3, the increases in employment are larger for wives of middle and high wage men (averaging around 35 percentage points) than the wives of low wage men (whose employment increased approximately 15 percentage points). Despite significant differences in the levels of employment across women with and without children, the changes in employment for these two groups over the past two decades have been remarkably similar.

\section{Changes in Earnings and Employment of Married Couples Over the 1960s}

The previous section summarized changes in male and female employment over the 1970 s and the 1980s. In this section we extend the period of our analysis by incorporating data from the 1960 Census. Our purpose in this section is two-fold. First, in analyzing the changes since 1969, we found that employment increased among all women but increased the most among wives of middle and high wage men. One natural question is whether this pattern is observable in previous periods. In other words, have wives of high wage men historically joined the labor force at a faster pace than wives of 
low wage men or is this a pattern that is unique to the 1970 s and the 1980s? Second, the 1960s provides an interesting contrast to the later period in that wage and employment differentials were stable or contracting over the 1960 s, while real earnings increased sharply for all wage categories of men over this same period.

In Figure 8 we present average female employment rates by husband's wage decile for 1959 in addition to 1969 and 1989. Again what is striking about Figure 8 is the cross sectional pattern of change, most notably the difference in the pattern of change in the early and the later periods. Figure 8 shows that during the 1960 s when wages were uniformly increasing for all men, the change in female employment was remarkably neutral across male wage categories. During the 1970 s and the 1980 s when relative wages and earnings were shifting dramatically in favor of high wage men, female employment also shifted towards these high wage households. Figure 8 clearly shows that the larger increases in employment we observe among wives of middle and high wage men is not an ongoing pattern but a pattern associated with the 1970 s and the 1980 s.

\section{The Role of Spouses' Earnings in Male and Female Labor Supply}

So far we have described the patterns of changes in employment and earnings for married men and their spouses over the three decades from 1959 to 1989 . Probably the most natural question to ask is how these changes are related to one another. In particular, to what extent can the fall in male employment be linked to the rise in the earnings of their spouses and to what extent can the growth in female employment rates be linked to the poor economic performance of their husbands? While both of these lines of thought are widely discussed there has been little systematic evidence brought to 
bear on either of these questions.

We begin with a comparison of the changes in employment of married men and women and changes in the earnings of their spouse. We perform this analysis for the aggregate as well as for the bottom, the middle and the top quintile groups. The top panel of Table 3 summarizes the changes in employment rates for wives and husbands in our sample over three decades, the 1960s, the 1970s, and the 1980s. The bottom panel gives the corresponding (log) changes in husbands' and wives' earnings.

We begin by comparing the time series changes in female employment rates shown in the top left-hand panel and the changes in male earnings shown in the bottom right hand panel to see whether female employment rates increased most sharply in those periods and for those households where male earnings declined the most. As can be seen from the table, the aggregate numbers suggest that female employment may have accelerated in the 1970s and the 1980s in response to a slowdown in male earnings. Employment of married women rose 11.9 percentage points from 1959 to 1969 as husbands' earnings rose 28.1 percent. The employment rate for these women then rose 13.5 and 13.0 percentage points in the 1970 s and the 1980 s as husbands' earnings growth slowed to 3.8 percent and 4.8 percent per decade respectively.

The cross effects story is not so convincing for the wives of low wage men. Among women married to men in the bottom quintile of the wage distribution employment increased 11.6 percentage points from 1959 to 1969 despite a 35.1 percent increase in their husband's earnings. Surprisingly the increase over the 1960s was larger than the 7.7 and 8.6 percentage point increases observed over the 1970s and the 1980 s when male earnings declined 11.6 percent and 21.6 percent respectively.

Evidence from Table 3 likewise casts some doubt on the claim that men reduced their time worked over the 1970 s and 1980 s in response to the increase in wives' 
earnings. In previous sections we found that employment declined primarily among low wage men. While the employment rates for these men fell over the 1970 s and 1980 s the earnings of their wives grew the most over the 1960s. As the table shows the employment rate of men in the bottom wage quintile increased 4.5 percentage points from 1959 to 1969 while the earnings of their wives grew 52.6 percent. In contrast employment rates for this same group fell by 7.6 and 4.7 percentage points over the 1970s and the 1980s when the earnings of their spouses increased 26.8 and 24.0 percent. As we have seen so far comparisons across different percentiles of the wage distribution as well as comparisons across time periods indicate that changes in earnings of the spouse certainly could not be the only factor leading to the changes in either male or female labor supply. In the following analysis we attempt to quantify how much if any of the observed changes in male and female labor supply can be linked to the changing employment and earnings patterns of the spouse. We begin by estimating the empirical relationship between the husband's employment rate and wife's earnings from the cross section, holding constant the husband's own wage and other characteristics such as education. We carry out a similar exercise for the wife. There is an extensive literature on estimating male and female labor supply equations. ${ }^{8}$ Our purpose here is not to introduce a richer structural model or a new estimation strategy that will improve upon previous studies, but to obtain cross sectional estimates from our data which lies within the range of estimates obtained by other studies and which we can use to predict employment changes. ${ }^{9}$ By comparing the actual changes in male and female

\footnotetext{
${ }^{8}$ Pencavel (1986) provides an excellent survey article on male labor supply while the review article by Heckman and Killingsworth (1986), Smith (1980), and Mroz (1987) are the standard references for female labor supply.

${ }^{9}$ Heckman and Killingsworth (1986) note that given the wide range of results reported on female labor supply elasticities, it is not difficult to find at least one other set of results similar to one's own.
} 
employment rates to the predicted changes, we can assess the relative importance of spouse's earnings as an explanation for the changes in employment of both married men and women.

We begin our analysis by posing a simple model of labor supply behavior of men and women. In this model, the male labor supply is given by

$$
E^{m}=\alpha_{0}+\alpha_{1} \ln \left(W^{m}\right)+\alpha_{2} Y^{m}+\alpha_{3}^{\prime} Z^{m}+e
$$

where $E^{m}$ is the husband's employment rate, $W^{m}$ is his hourly wage rate, $Y^{m}$ is his nonlabor income including the earnings of the wife, $Z^{m}$ is a vector of other variables which may also affect his employment and $e$ is the disturbance term. Notice that in this model, the effect of wife's earnings enters only through the parameter $\alpha_{2}$ which measures the effect of nonlabor income on employment. ${ }^{10}$ For women we have the analogous equation

$$
E^{f}=\beta_{0}+\beta_{1} \ln \left(W^{f}\right)+\beta_{2} Y^{f}+\beta_{3}^{\prime} Z^{f}+\epsilon .
$$

In what follows we estimate parameters in equations (1) and (2) using cross sectional data. Using our data of matched husband-wife couples, we estimate equations (1) and (2) for the three time periods, 1968-70, 1978-80 and 1988-90. The dependent variables are the husband's and the wife's employment rate defined as the fraction of

\footnotetext{
10 Thedirect cross-effect between wife's earnings and husband's labor supply due to complementarity and substitutability of leisure is restricted to equal zero in this model. We also tested specifications where the spouse's wage and nonlabor income (excluding transfers) enter separately in the employment equations. The estimated income effect fluctuates across different years and is large and positive in 1988-90. The instability of these estimates may be due to severe under-reporting of income data (other than earnings) on the CPS. For further discussion of these problems, see Smith (1980).
} 
weeks an individual was employed in a given year. We predict wages for non-working individuals using the husband's wage decile dummies, husband's and wife's education dummies, dummy variables for children aged 1-6 and children aged 7-17, age and age squared of the wife, region dummies and year dummies. "Nonlabor income" is the sum of non-wage income of the husband and the wife plus the earnings of the spouse measured in thousands of 1982 dollars.

We report our estimates for the male employment equation in Table 4. We use actual reported hourly wages of husbands in the regressions but instrument these reported wages with the wage decile dummies (corrected for measurement error and imputed for non-workers) to minimize the effect of measurement error in wages. In addition, to allow employment to be more responsive at low wages, we estimate the wage parameter, $\alpha_{1}$, via three linear splines defined for wages in approximately the 1-20, 21-40 and $41+$ percentile ranges. Since wife's earnings are likely to be endogenous to husband's employment rate, we estimate the effect of husband's nonlabor income using two alternative instruments. The first specification, reported in columns (1)-(3), uses the wife's log hourly wage to instrument for the husband's nonlabor income. In the second specification, reported in columns (4)-(6), we use dummy variables for the presence of children aged 1-6 and children aged 7-17 as instruments. Our estimates of the nonlabor income effect vary somewhat with our choice of instruments. Both the wife's wage and dummy variables for children have their respective problems as instruments and may lead to different biases in our estimates. For example, the extremely small effect of wife's earnings we estimate when we use the wife's wage as an instrument may be due to positive assortive mating. That is, it may be the case that women who have higher than average wages tend to marry men who have both high wages and high employment rates for a given wage. This latter positive correlation between wife's wage and husband's 
employment rate would tend to positively bias our estimate from these specifications towards zero. On the other hand, using children as instruments for wife's earnings may actually lead to a bias in the opposite direction. If children induce husbands to work more even holding constant the wife's earnings and husband's wage this would tend to make our estimates from this specification somewhat too large. ${ }^{11}$ With these reservations about our instruments in mind, we describe our results below.

First, we estimate a relatively small "nonlabor income" effect for husbands. For example, the largest nonlabor income effect we report in Table 4 is -.0014 (reported in column (6) of Table 4) which implies that a $\$ 1000$ increase in wife's earnings would lead to slightly more than 0.1 percentage point decline in the husband's employment rate translating into an elasticity of approximately -.04. However, since the decline in employment occurred predominantly among low wage men, we are particularly interested in the effect of nonlabor income and wife's earnings on the employment of low wage men. We therefore restrict the sample to low wage men whose wages fell in the bottom quintile of the wage distribution and report the estimates of the same model for this sample in Table 5. For the sample of low wage men, the largest estimate we obtain is .0112 in 1988-90 which translates into an elasticity of about -.11. Employment among these low wage men declined approximately 12 percentage points from 1969 to 1989. The increase in wife's earnings could potentially account for up to 2 percentage points (or 18 percent) of this decline. ${ }^{12}$

Our other findings of interest in Table 4 and Table 5 pertain to wage elasticities.

\footnotetext{
${ }^{11}$ Pencavel(1986) notes that when the number of dependents are added to the male labor supply equation, it is generally positively associated with hours of work.

${ }^{12}$ The list of estimates for the nonlabor income elasticity documented by Pencavel (1986) range from -.29 to .02 while the estimates of the compensated wage elasticity range from .05 to .19 . Our findings are in general agreement with these findings in that we find the compensated wage elasticity to be a small positive number and the income elasticity to be a small negative number for men overall.
} 
We find here as we have elsewhere (see Juhn (1992) and Juhn, Murphy and Topel (1992)) that male labor supply is positively related to wages and is significantly more elastic at low wages. For example, we find that in $1988-90$ a $10 \%$ increase in the hourly wage increases male employment by approximately 2.5 percentage points at wages below the 20th percentile (for an elasticity of about .31 ) but has a trivial effect on employment at wages above the 40th percentile. Thus, any discussion of the male labor supply elasticity would appear to depend crucially on the wage levels of the men in question. The second finding of note is that the male labor supply elasticity estimated from the cross section has increased considerably over the years. For example, for men with wages below the 20th percentile, the partial labor supply elasticity is only .0953 in 1968 70 (column (4) of Table 4) but we estimate a partial elasticity as large as .2473 in 198890. This increase over the years implies that labor supply elasticities estimated from the cross section also depend crucially on the time period studied.

To summarize, based on our estimates from cross sectional data, we find that an increase in wife's earnings leads to a trivial decline in husband's employment for men overall but a modest decline in employment among low wage men. For men with low wages who have had the largest employment declines, the fall in their wages can account for somewhere between 20-50 percent of the employment decline since 1969 while the increase in wife's earnings could account for somewhere between 5 to 20 percent. Our conclusion is that the own wage effect dominates the effect of wife's earnings in explaining the decline in male employment.

In Table 6 we present estimates for the wife's employment equation analogous to those reported for men in Table 4. In order to preserve simplicity as well as due to a lack of adequate instruments, we ignore a number of issues in our estimation of the woman's employment equation which may be important and have been the focus of 
research in many previous papers. ${ }^{13}$ For one, we do not address the issue of selection bias which may result from imputing wages for nonworkers based on data from working women, and in general do not allow for the fact that wages may be endogenous. We also sidestep the question of endogenous marriage and fertility decisions. We report results for specifications with and without controlling for the presence of children aged 16 and children aged 7-17. In both specifications, we use dummy variables for the husband's wage decile to instrument for the wife's nonlabor income.

As was the case with men, the estimates for the women vary considerably over different time periods. In general, the cross sectional relationship between female employment and wages appears to have grown stronger over time while the relationship between wife's employment and husband's earnings appears to have grown weaker over time. This latter finding is consistent with Figure 3 which indicated that the largest increases in employment occurred among women married to men with relatively high wages and earnings.

As we report in the first row of Table 6, we estimate that a $10 \%$ increase in the wife's own wage would lead to a 0.2 percentage point increase in her employment rate in 1968-70 and approximately 1.0 percentage point increase in 1988-90. This latter estimate translates into an elasticity of about .15 which is considerably larger than the male labor elasticity at the mean wage although not nearly as large as some estimates which have been proposed in the literature. ${ }^{14}$

${ }^{13}$ Mroz (1987) provides the most complete sensitivity analysis of the consequences of different strategies adopted in estimating female labor supply. His results are not directly comparable to ours since his dependent variable is annual hours worked among working women while our variable, the fraction of weeks an individual is employed (including zero weeks worked), is more of a participation measure. However, his conclusion that the female labor supply elasticities may be smaller than previously thought is generally in line with the relatively small responses we observe in our data.

14 Heckmanand Killingsworth (1986) document reported estimates of the compensated wage elasticity which are as high as 15. In general, it has not been uncommon to find wage elasticities greater than 1.0 for women. 
The effect of husband's earnings on the wife's employment is also larger than that estimated for the effect of wife's earnings on the husband's employment rate. Controlling for the presence of children, we estimate that a $\$ 1000$ decrease in husband's earnings would have increased the wife's employment rate by 0.7 percentage points in 1968-70 and by 0.4 percentage points in $1988-90$. Overall, employment increased by about 27 percentage points for married women in our sample from 1969 to 1989 . Based on our estimates, the increase in women's wages would account for at most 6-7 percent of the total increase in women's employment. Since husbands' earnings in the aggregate increased slightly from 1969 to 1989 , we would actually predict women's employment to fall slightly based on this factor alone. For women married to men in the bottom quintile of the wage distribution, husbands' earnings declined nearly 30 percent. This would account for approximately 2.8 percentage points of the total increase of 16.3 percentage points among these women since 1969. Clearly, shifts in female labor supply is the overwhelming effect even for these women in low wage households.

Finally, we note that as expected, the presence of children has a large negative effect on female employment. The presence of children aged 1-6 lowers the wife's employment rate somewhere between 18 to 22 percentage points. If we were to simply treat children as an exogenous variable, this would imply that the decline in the number of households with children could account for somewhere between 2 to 3 percentage point increase in female employment. We also note that the negative relationship between children and female employment has grown weaker over the period 1969 to 1989 indicating that increases in employment have been equally large if not larger among women with children than among women without children.

Given that labor supply of married women has been on the increase well before the deterioration in male earnings, it is not too surprising that we predict a trivial 
increase in female labor supply based on male earnings. A somewhat more reasonable question is whether the slowdown in male earnings growth in the 1970s and the 1980s can to any degree account for the acceleration of the growth in female employment witnessed in these same two decades. We address this question in Table 7.

In Table 7 we start by comparing the change in married women's employment rate over the period 1959-1969 to the change over the latter period 1969-1989. Since we are interested in comparing growth rates, we report changes on a per decade basis in column (1) and column (2) of Table 7. To arrive at the predicted change reported in column (3) we multiplied the change in husbands' earnings over the period 1969-1989 minus the corresponding change for $1959-1969$ by the coefficient -.004 (our estimate of the nonlabor income effect reported in column (3) of Table 6) and added this amount to the base period change observed over 1959-1969. As Table 7 indicates, married women's employment rate accelerated slightly, growing at a rate of 11.9 percentage points per decades over the 1960s and growing at a rate of 13.3 percentage points per decade during the 1970s and 1980s. Based on the slowdown in husband's earnings we would have predicted the entire 1.4 percentage point acceleration and more.

The 1.4 percentage point acceleration seen in the aggregate, however, masks an actual deceleration of more than 3 percentage points for women in low-wage households and an acceleration of 5 percentage points for women in high-wage households. As can be seen in the table, while the predicted acceleration in female employment growth was greatest for the wives of low-wage men, the actual acceleration occurred for the wives of high-wage men. Table 7 indicates that changes in husband's earnings is unable to predict the biased growth in female employment towards high wage households which has been a major development in female labor supply in recent decades. 


\section{Conclusion}

The results in this paper suggest that in the aggregate the slowdown in men's earnings appears to have contributed somewhat to the acceleration of married women's employment during the recent decades. Further analysis, however, shows that this acceleration is not the major quantitative change in female labor supply witnessed over the past two decades. Instead we find that the last two decades have been a time where the relative participation rates of married women have shifted enormously, with the wives of high wage men increasing their employment rates significantly more than the wives of low wage men. Since the slowdown in male earnings growth was greatest for low wage men and smallest for high wage men these relative shifts run completely contrary to what would be expected based on a simple cross effects story.

The major challenge then is to identify what forces have served to counteract the cross sectional impact of the slowdown in husband's earnings growth that seems to fit the aggregate data so well. While we have no real answers to this question we have a few preliminary ideas. First, changes in women's wages and market opportunities appears to be consistent with biased growth in female employment since wage growth of women in low wage households slowed considerably while wage growth of women in high wage households held steady during the 1970 s and the 1980s as compared to the 1960 s. The actual impact of changes in market opportunities may have been even greater than observed in cross sectional data in that the entry of women with low levels of experience and changing composition of working women most probably understated increasing wage opportunities for women (see, for example, Smith and Ward (1989)). If experience and investments in human capital are particularly important for high wage women then wage growth may be especially understated for women in high wage households. In addition, a 
sharp non-neutral shift in labor supply for men between the late 1960s and the early 1970s suggests that similar forces may have been at work for low wage women over the same period. We intend to address these issues in our future work. 


\section{Appendix}

\section{A. Imputation of Wages for Nonworking Males}

The Annual Demographics Supplement on the March CPS contains retrospective earnings and employment information for the year previous to the survey. This design allows us to calculate hourly wages even for men who only worked part of the year. However, a significant portion of prime-age men do not work at all during the year and have missing wage data. For example, 4.7 percent of the men with 1 to 30 years of potential labor market experience who were not enrolled in school or in the military did not work at all during 1989. Following a method first introduced in our previous papers (Juhn (1992) and Juhn, Murphy, and Topel (1991)) we impute the potential wage offer distribution of these nonworking men using the distribution of observed wages of men who worked very little, namely $1-13$ weeks.

There are a number of reasons to believe that the wages of those who worked very little may be a close proxy of the unobserved wage offers of nonworking men. For example, the educational attainment of the two groups are similar in that approximately 43.6 percent of the nonworkers were high school dropouts and only 7.5 percent were college graduates during the $1982-89$ period. Among men who worked 1-13 weeks, 38.5 percent were high school dropouts and 7.3 percent were college graduates. Even more telling is the comparison of survey week wages. For those men who did not work the entire year but re-entered the labor market in the following year, we have valid survey week wages for the outgoing rotation samples beginning in 1982. These men had average wages approximately 43 percent below the mean of their cohort. Using the same outgoing rotaion samples we calculated the average survey week wages of those who worked 1-13 weeks the previous year and found it was also approximately 43 
percent below the mean.

To estimate the full wage offer distribution (including those offered to nonworkers) we first divided the sample of prime-age men to 72 groups based on 6 experience groups, 4 education groups, and 3 marital status groups defined as single, married with a working spouse, and married with a nonworking spouse. For each group in each year, we then reweighted each male who worked 1-13 weeks by the factor $(1+$ $\left.N_{0} / N_{1-13}\right)$ where $N_{0}$ is the number of non-workers and $N_{1-13}$ is the number of workers who worked 1-13 weeks within the group. Alternatively we could have run a wage equation with bracketed weeks worked last year as an additional regressor and predicted wages for nonworkers. We view our method as preferable, however, in that we are using information on the full distribution of wages of part-year workers and not just the means.

\section{B. Correction for Measurement Error in Wages}

While organizing the data based on the husband's wage percentile is an important innovation in our paper, one problem with our wage-based approach is measurement error in wages. Measurement error is an especially serious problem in our data in that we calculate hourly wages by dividing annual earnings by annual hours worked. If weeks are measured with error, this results in a spurious negative relationship between weeks and hourly wages. In our previous work, we have compared the distribution of wages based on retrospective March data (calculated by dividing annual earnings by annual hours) with the distribution of reported hourly wages from the survey week data available for the outgoing rotation samples since 1982 . We have found that the variance of calculated wages is much larger than the variance of reported wages, particularly in the low weeks worked categories. For example, for those who worked 1-13 weeks, the variance of $\log$ hourly wages calculated from annual earnings and hours was .69 while 
the variance of reported wages was .24 . This suggested to us that we were misclassifying a significant number of men in the low weeks worked categories to high wage categories due to measurement error.

While measurement error in survey week wages remains a problem, we partially correct the distribution in calculated wages by using the distribution of reported survey week wages. Using data from the outgoing rotation samples for 1982-92, we calculated for each weeks worked bracket and percentile category the difference in log wages necessary to make the two distributions equal. We then applied this correction factor to calculated hourly wages for all years 1967-91. 


\section{References}

Blackburn, Mckinley L. and David E. Bloom. "Changes in the Structure of Family Income Inequality in the U.S. and Other Industrialized Nations during the 1980s." Unpublished paper, University of South Carolina and Columbia University, 1990.

Cancian, Maria, Sheldon Danziger, and Peter Gottschalk. "Working Wives and Family Income Inequality among Married Couples." In Uneven Tides: Rising Inequality in America, edited by Sheldon Danziger and Peter Gottschalk, pp. 195-222. New York: Russell Sage Foundation, 1993.

Coleman, Mary T. and John Pencavel. "Trends in Market Work Behavior of Women Since 1940." Industrial and Labor Relations Review 46 (July 1993): 653-676.

Goldin, Claudia. "Life-Cycle Labor-Force Participation of Married Women: Historical Evidence and Implications." Journal of Labor Economics 7 (January 1989): 20-47.

Heckman James J. and Mark R. Killingsworth. "Female Labor Supply: A Survey." In Handbook of Labor Economics 1, edited by Orley C. Ashenfelter and Richard Layard, pp. 103-204. New York: North-Holland, 1986.

Juhn, Chinhui. "Decline of Male Labor Market Participation: The Role of Declining Market Opportunities." Quarterly Joumal of Economics 107 (February 1992): 79121.

Juhn, Chinhui, Murphy, Kevin M., and Robert H. Topel. "Why Has the Natural Rate Increased with Time?" Brookings Papers on Economic Activity 2 (1991):75-142.

Karoly, Lynn A. "The Trend in Inequality Among Families, Individuals, and Workers in the United States: A 25-Year Perspective." In Uneven Tides: Rising Inequality in America, edited by Sheldon Danziger and Peter Gottschalk, pp. 19-98. New York: Russell Sage Foundation, 1993.

Katz, Lawrence and Murphy, Kevin M. "Changes in Relative Wages, 1963-87: Supply and Demand Factors." Quarterty Journal of Economics 107 (February 1992): 35-78.

Levy, Frank and Murnane, Richard J. "U.S. Earnings levels and Earnings Inequality: A Review of Recent Trends and Proposed Explanations." Joumal of Economic Literature 30 (1992): 1333-1381. 
Mroz, Thomas A. "The Sensitivity of an Empirical Model of Married Women's Hours of Work to Economic and Statistical Assumptions." Econometrica 55 (July 1987): $765-799$.

Pencavel, John. "Labor Supply of Men: A Survey." In Handbook of Labor Economics 1, edited by Orley C. Ashenfelter and Richard Layard, pp. 3-102. New York: North-Holland, 1986.

Smith, James P. “Assets and Labor Supply." In Female Labor Supply: Theory and Estimation, edited by James P. Smith, pp.166-205. New Jersey: Princeton University Press, 1980.

Smith, James P., and Michael Ward. "Time Series Growth in the Female Labor Force." Journal of Labor Economics 3 (January 1985): 59-90.

Smith, James P., and Michael Ward. "Women in the Labor Market and in the Family." Joumal of Economic Perspectives 3 (Winter 1989): 9-23. 
Table 1

Log Change in Wife's Annual Hours Worked and Componenta: 1969-1989

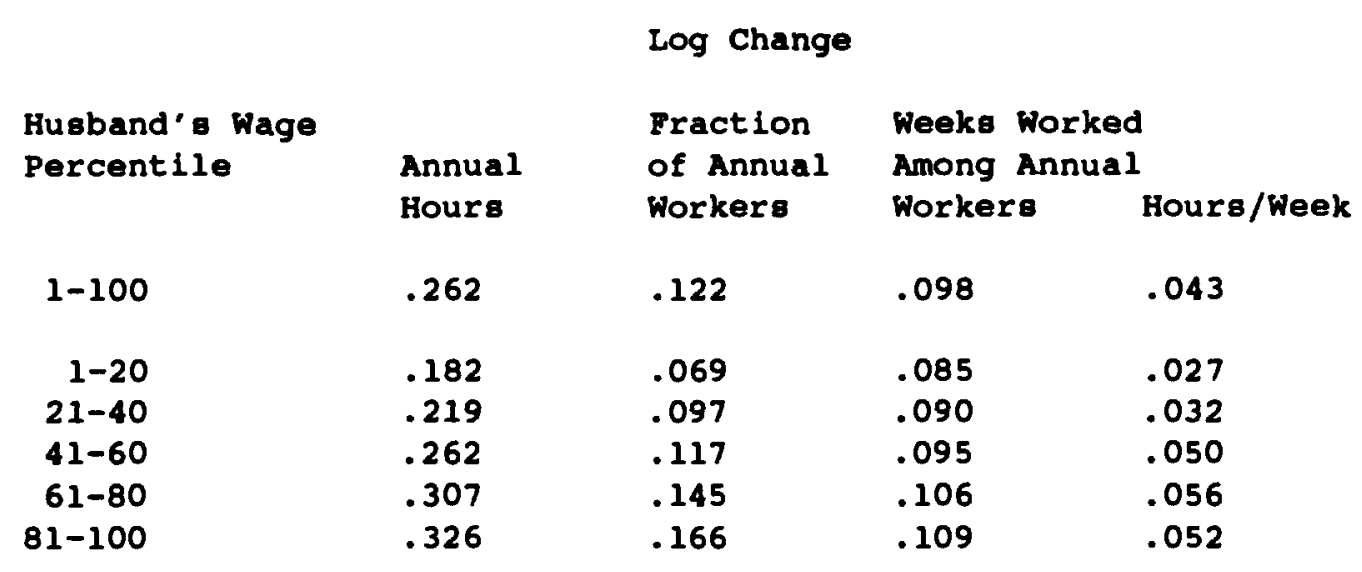

Source: March Current Population Surveys 1968-1991. The sample includes all matched husband-wife pairs where the husband had 1-30 years of potential labor market experience, where neither spouse lived in group quarters, where neither spouse was in school or the military service. Three year averages were taken around the years 1969 and 1989. "Annual hours" are average annual hours worked among all wives in the sample and in each wage quintile category. Average annual hours are the product of the fraction of wives who worked at least 1 week during the previous year, average weeks worked among annual participants, and average hours worked per week among workers in any given week. The table presents the log change in total annual hours as well as the log change in the components. 
Table 2

Changes in Wife's Employment and Fertility: 1969-1989

Change 1969-1989

(1)

Husband's Wage
Percentile Fraction w/o
Children

.097

.069

.077

.091

.105

.131
(2)

Actual Change

in Wife' $a$

Employment

.271

.163

.243

.282

.308

.332
.251

(3)

Change in Wife's

Employment--

Composition Fixed

.144

.227

.264

.288

.303

Source: March Current Population Surveys 1968-1991. The sample includes all matched husband-wife palrs where the husband had 1-30 years of potential labor market experience, where neither spouse lived in group quarters, where neither spouse was in school or military service. Three year averages were taken around the years 1969 and 1989 . Column (3) reports changes in wife's employment rate holding the composition of women across three fertility classes-- women without children, women with children aged 16, and women with children aged 7-18-- fixed across the 1969-89 period. 
Changes in Husband's and Wife's Bmployment and Earnings By Husband's Hage Percentile

A. Change in the Employment Rate

\begin{tabular}{ccccccccc} 
& \multicolumn{3}{c}{ Wife } & & & \multicolumn{2}{c}{ Husband } \\
& & & & & & \\
& $59-69$ & $69-79$ & $79-89$ & & $59-69$ & $69-79$ & $79-89$ \\
$\begin{array}{c}\text { Husband's Wage } \\
\text { Percentile }\end{array}$ & & & & & & & \\
$1-20$ & .116 & .077 & .086 & & .045 & -.076 & -.047 \\
$41-60$ & .128 & .142 & .134 & & .024 & -.020 & .006 \\
$81-100$ & .109 & .173 & .148 & & .014 & -.002 & .008 \\
$1-100$ & .119 & .135 & .130 & & .026 & -.024 & -.002
\end{tabular}

B. Log Change in Earnings

\section{wife}

$59-69 \quad 69-79 \quad 79-89$

Husband's Wage

Percentlle

$1-20$

41-60

81-100

$.526 \quad .268 \quad .240$

$.527 \quad .346 \quad .371$

$.589 \quad .535 \quad .545$

$1-100$

$.530 \quad .382 \quad .406$
Husband

$\begin{array}{lll}59-69 & 69-79 & 79-89\end{array}$

$.351-.116-.216$

$.269 \quad .015-.022$

$.281 \quad .061 \quad .112$

$\begin{array}{lll}.281 & .038 \quad .048\end{array}$

Source: See Table 1 . 
Table 4

Estimates of the Husband's Employment Equation

Dependent Variable = Husband's Employment Rate

\begin{tabular}{|c|c|c|c|c|c|c|}
\hline & & & & YEAR & & \\
\hline & $\begin{array}{l}1968-70 \\
(1)\end{array}$ & $\begin{array}{l}1978-80 \\
(2)\end{array}$ & $\begin{array}{l}1988-90 \\
\text { (3) }\end{array}$ & $\begin{array}{l}1968-70 \\
(4)\end{array}$ & $\begin{array}{l}1978-80 \\
(5)\end{array}$ & $\begin{array}{l}1988-90 \\
(6)\end{array}$ \\
\hline Log Hourly Wage & & & & & & \\
\hline Percentile $1-20$ & .0937 & .1680 & .2452 & .0953 & .1690 & .2473 \\
\hline & $(.0106)$ & $(.0103)$ & $(.0088)$ & $(.0105)$ & $(.0102)$ & $(.0088)$ \\
\hline Percentile 21-40 & .0738 & .1540 & .1307 & .0790 & .1496 & .1342 \\
\hline & $(.0105)$ & $(.0133)$ & $(.0139)$ & $(.0104)$ & $(.0133)$ & $(.0140)$ \\
\hline Percentile $41+$ & -.0105 & .0063 & .0060 & -.0145 & .0074 & .0032 \\
\hline & $(.0034)$ & $(.0038)$ & $(.0039)$ & $(.0033)$ & $(.0038)$ & $(.0039)$ \\
\hline Nonlabor & .0006 & .0001 & -.0004 & -.0014 & -.0006 & -.0014 \\
\hline Income & $(.0003)$ & $(.0002)$ & $(.0002)$ & $(.0003)$ & $(.0003)$ & $(.0004)$ \\
\hline Number of $\mathrm{Obs}$. & 45,490 & 52,679 & 46,959 & 45,490 & 52,679 & 46,959 \\
\hline R-squared & .0083 & .0276 & .0309 & .0231 & .0466 & .0238 \\
\hline
\end{tabular}

Source: March Current Population Surveys. See notes to Table 1 for sample selection criteria.

Notes: Estimates in columns (1)-(3) use as instruments dummy variables for the husband's wage decile and wife's wage. Estimates in columns (4)-(6) use dummy variables for the husband's wage decile and dummy variables for children aged $1-6$ and children aged 7-17. Wages are log average hourly earnings computed as the natural logarithm of annual wage and salary earnings divided by weeks worked times usual weekly hours. Three separate wage coefficients are estimated via linear splines defined for wages in 1-20, $21-40$, 41+ percentile ranges. Nonlabor income is measured as the sum of the non-wage income for the husband and wife plus the wife's total earnings (wage and salary income plus income from self employment) in $\$ 1,000$.

Additional right hand side variables in the regression which we do not report here include region dummies, year dummies, and husband's education. Since we restrict our sample to prime-age males, we assume that age per se does not directly affect male employment rates. 


\section{Table 5}

Eat Imates of the Husband's Employment Equation: Percent11es 1-20

Dependent Variable = Husband's Employment Rate

\begin{tabular}{|c|c|c|c|c|c|c|}
\hline & $\begin{array}{l}1968-70 \\
\text { (1) }\end{array}$ & $\begin{array}{l}1978-80 \\
(2)\end{array}$ & $\begin{array}{l}1988-90 \\
(3)\end{array}$ & $\begin{array}{l}1968-70 \\
(4)\end{array}$ & $\begin{array}{l}1978-80 \\
(5)\end{array}$ & $\begin{array}{l}1988-90 \\
(6)\end{array}$ \\
\hline Log Hourly Wage & $\begin{array}{l}.1132 \\
(.0123)\end{array}$ & $\begin{array}{l}.1824 \\
(.0145)\end{array}$ & $\begin{array}{l}.2562 \\
(.0201)\end{array}$ & $\begin{array}{l}.1172 \\
(.0122)\end{array}$ & $\begin{array}{l}.1795 \\
(.0144)\end{array}$ & $\begin{array}{l}.2568 \\
(.0222)\end{array}$ \\
\hline $\begin{array}{l}\text { Nonlabor } \\
\text { Income }\end{array}$ & $\begin{array}{l}-.0029 \\
(.0009)\end{array}$ & $\begin{array}{l}-.0036 \\
(.0009)\end{array}$ & $\begin{array}{l}-.0055 \\
(.0009)\end{array}$ & $\begin{array}{l}-.0046 \\
(.0016)\end{array}$ & $\begin{array}{l}-.0040 \\
(.0012)\end{array}$ & $\begin{array}{l}-.0112 \\
(.0030)\end{array}$ \\
\hline $\begin{array}{l}\text { Number of Obs. } \\
\text { R-squared }\end{array}$ & $\begin{array}{r}7.783 \\
----\end{array}$ & 8,940 & $\begin{array}{r}7,621 \\
----\end{array}$ & $\begin{array}{r}7.783 \\
----\end{array}$ & 8,940 & 7,621 \\
\hline
\end{tabular}

Source: March Current Population surveys. See notes to Table 1 for sample selection criteria. Notes: See Table 4. 
Estimates of the Wife's Employment Equation

Dependent Variable $=$ Wife's Employment Rate

\begin{tabular}{|c|c|c|c|c|c|c|}
\hline & $\begin{array}{l}1968-70 \\
(1)\end{array}$ & $\begin{array}{l}1978-80 \\
(2)\end{array}$ & $\begin{array}{l}1988-90 \\
(3)\end{array}$ & $\begin{array}{l}1968-70 \\
(4)\end{array}$ & $\begin{array}{l}1978-80 \\
(5)\end{array}$ & $\begin{array}{l}1988-90 \\
(6)\end{array}$ \\
\hline Log Hourly Wage & $\begin{array}{l}.0210 \\
(.0042)\end{array}$ & $\begin{array}{l}.0969 \\
(.0044)\end{array}$ & $\begin{array}{l}.0994 \\
(.0041)\end{array}$ & $\begin{array}{l}.0373 \\
(.0044)\end{array}$ & $\begin{array}{l}.1139 \\
(.0046)\end{array}$ & $\begin{array}{l}.1036 \\
(.0042)\end{array}$ \\
\hline Nonlabor Income & $\begin{array}{l}-.0071 \\
(.0002)\end{array}$ & $\begin{array}{l}-.0051 \\
(.0002)\end{array}$ & $\begin{array}{l}-.0040 \\
(.0001)\end{array}$ & $\begin{array}{l}-.0076 \\
(.0002)\end{array}$ & $\begin{array}{l}-.0053 \\
(.0002)\end{array}$ & $\begin{array}{l}-.0041 \\
(.0001)\end{array}$ \\
\hline Children Under 6 & $\begin{array}{l}-.2242 \\
(.0049)\end{array}$ & $\begin{array}{l}-.2304 \\
(.0048)\end{array}$ & $\begin{array}{l}-.1824 \\
(.0048)\end{array}$ & --- & --- & --- \\
\hline Children Aged 7-17 & $\begin{array}{l}-.1488 \\
(.0059)\end{array}$ & $\begin{array}{l}-.1271 \\
(.0054)\end{array}$ & $\begin{array}{l}-.0952 \\
(.0050)\end{array}$ & ---- & --- & --- \\
\hline $\begin{array}{l}\text { Number of Obe. } \\
\text { R-Squared }\end{array}$ & $\begin{array}{r}45,490 \\
.1371\end{array}$ & $\begin{array}{r}52,679 \\
.1004\end{array}$ & $\begin{array}{r}46,959 \\
.1229\end{array}$ & $\begin{array}{r}45,490 \\
.0442\end{array}$ & $\begin{array}{r}52,679 \\
.0018\end{array}$ & $\begin{array}{r}46,959 \\
.0619\end{array}$ \\
\hline
\end{tabular}

Source: March Current Population Surveys. See notes to Table 1 for sample selection criteria.

Notes: "Log hourly wage" is log average hourly earnings of the wife computed as the natural logarithm of annual wage and salary earnings divided by weeks worked times usual weekly hours. Wages for non-workers are predicted using the husband's wage decile dummies, husband's and wife's education, dumny variables for children, wife's age, region and year dummies. "Nonlabor income" is measured as the sum of the non-wage income for the husband and wife plus the husband's total earnings (wage and salary income plus income from self employment) in $\$ 1,000$. We use as instruments dummy variables for the husband's wage decile.

Additional right hand side variables in the regression which we do not report here include region dumies, year dummies, wife's age and age squared, and wife's education. 
Table 7

Rates of Change in Wife's Employment Rate (per decade)

(1)

Actual Change

.117

.121

.128

.119

.119
(2)

Actual Change

.083

.120

.133
(3)

Predicted Change

.135
.140
.148
.139
.132

.138

\footnotetext{
of men in the indicated wage decile categories between 1959 and 1969. Column

(2) gives the average change in employment rates for the wives of the same groups of men over the period 1969-1989 on a per decade basis. Column (3) 1989 as the per decade rate from 1959 to 1969 minus .004 times the difference in the changes in husband's earnings (again measured per decade) between the 1969-1989 and the 1959-1969 periods. This column represents the forecasted growth in employment for each group based on its earlier growth and the change income effect from column (3) of Table 6 .
} 


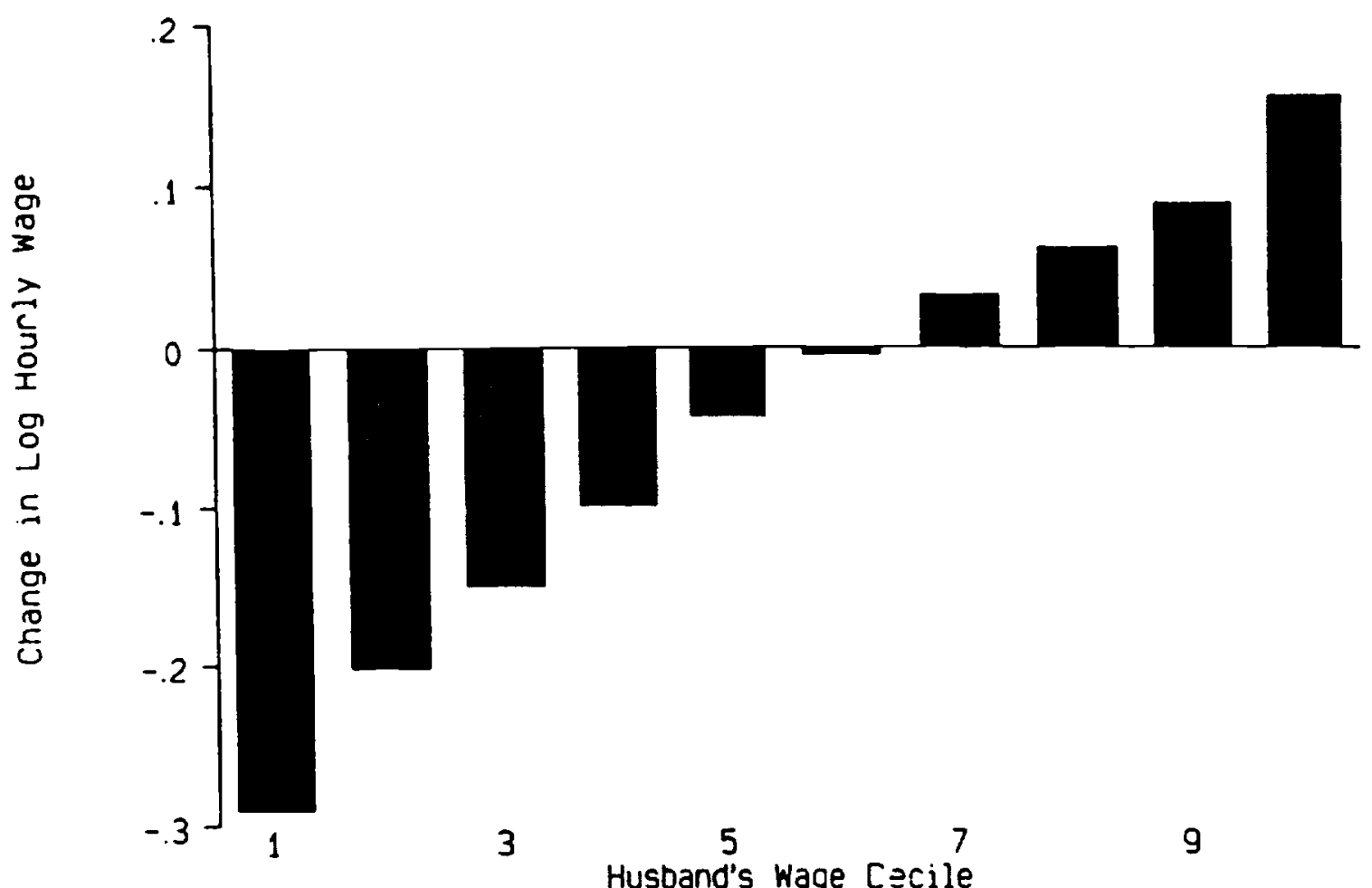

Figure 1. Change in Husband's Log Hourly Wage 1969-1989 


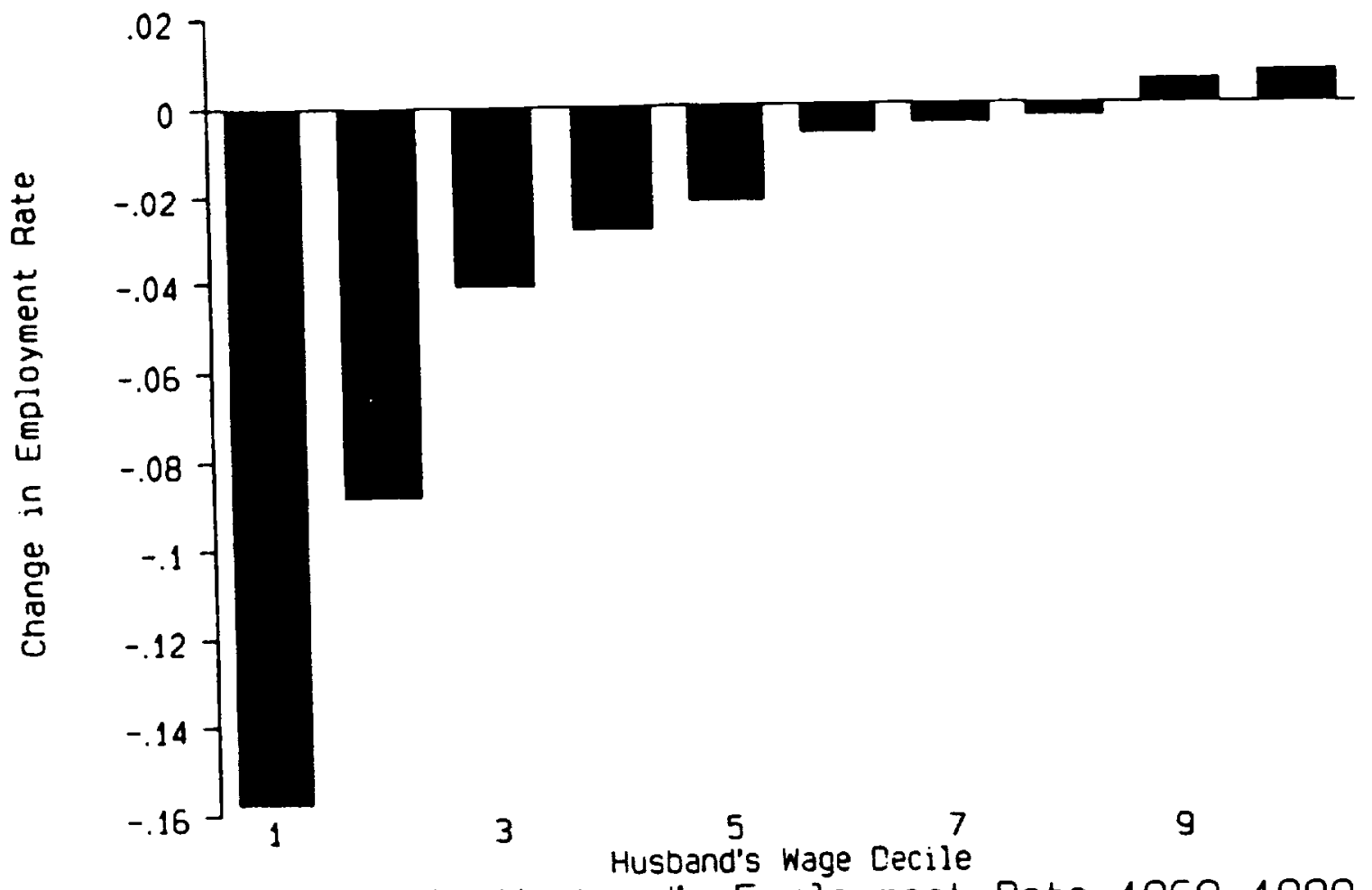

Figure 2. Change in HusDand's Employment Rate 1969-1989 


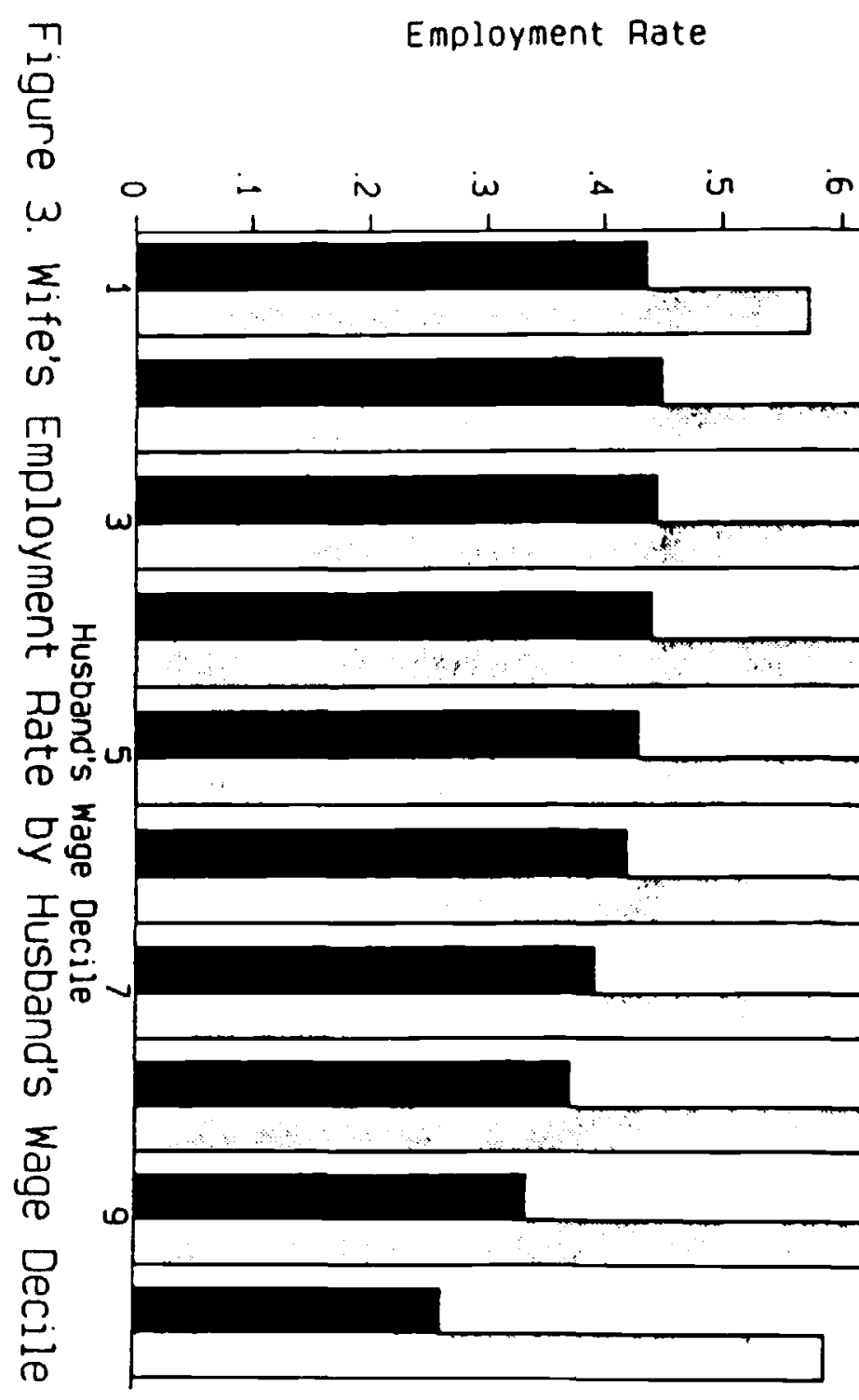




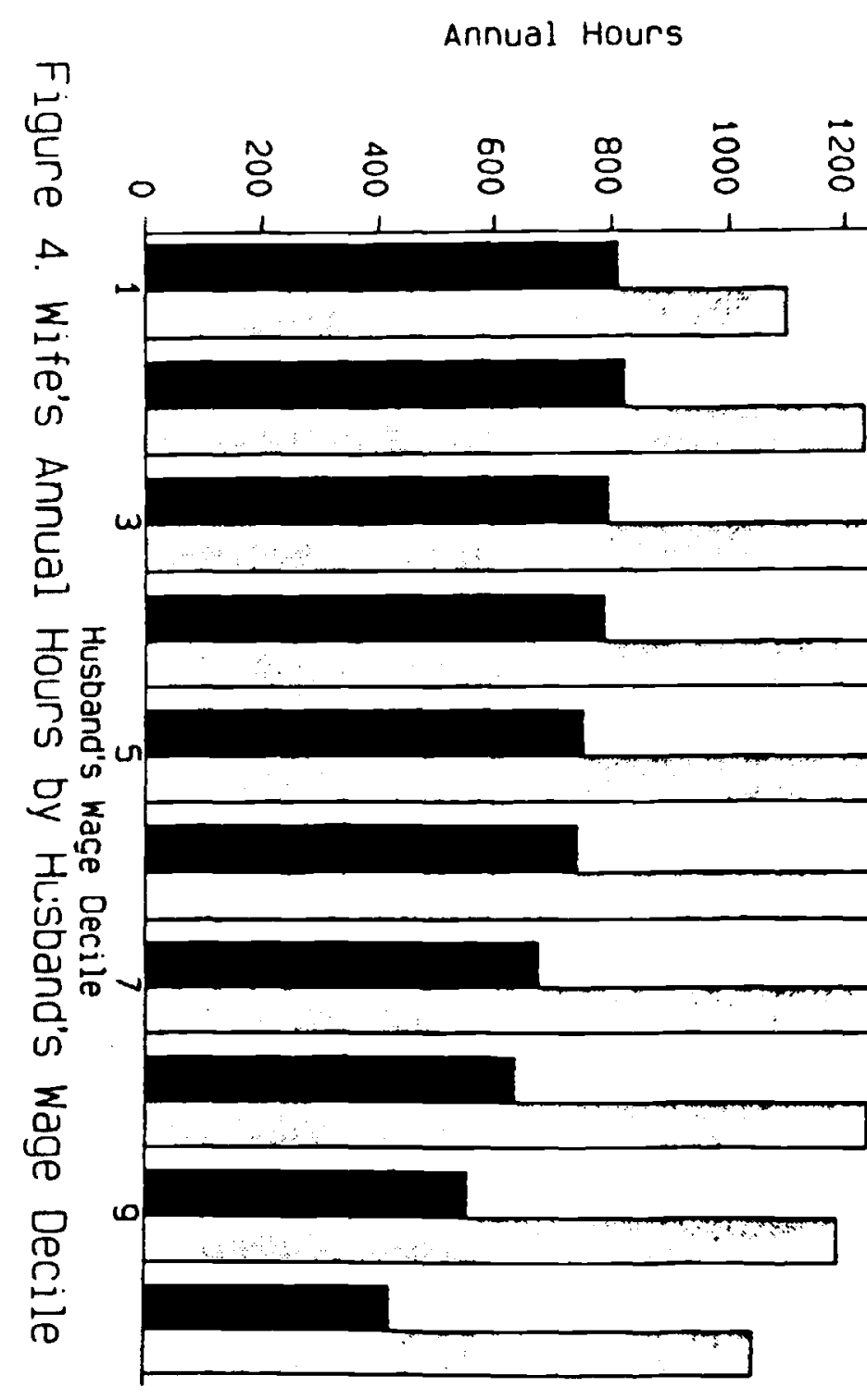


Hourly Wage $1982 \$$

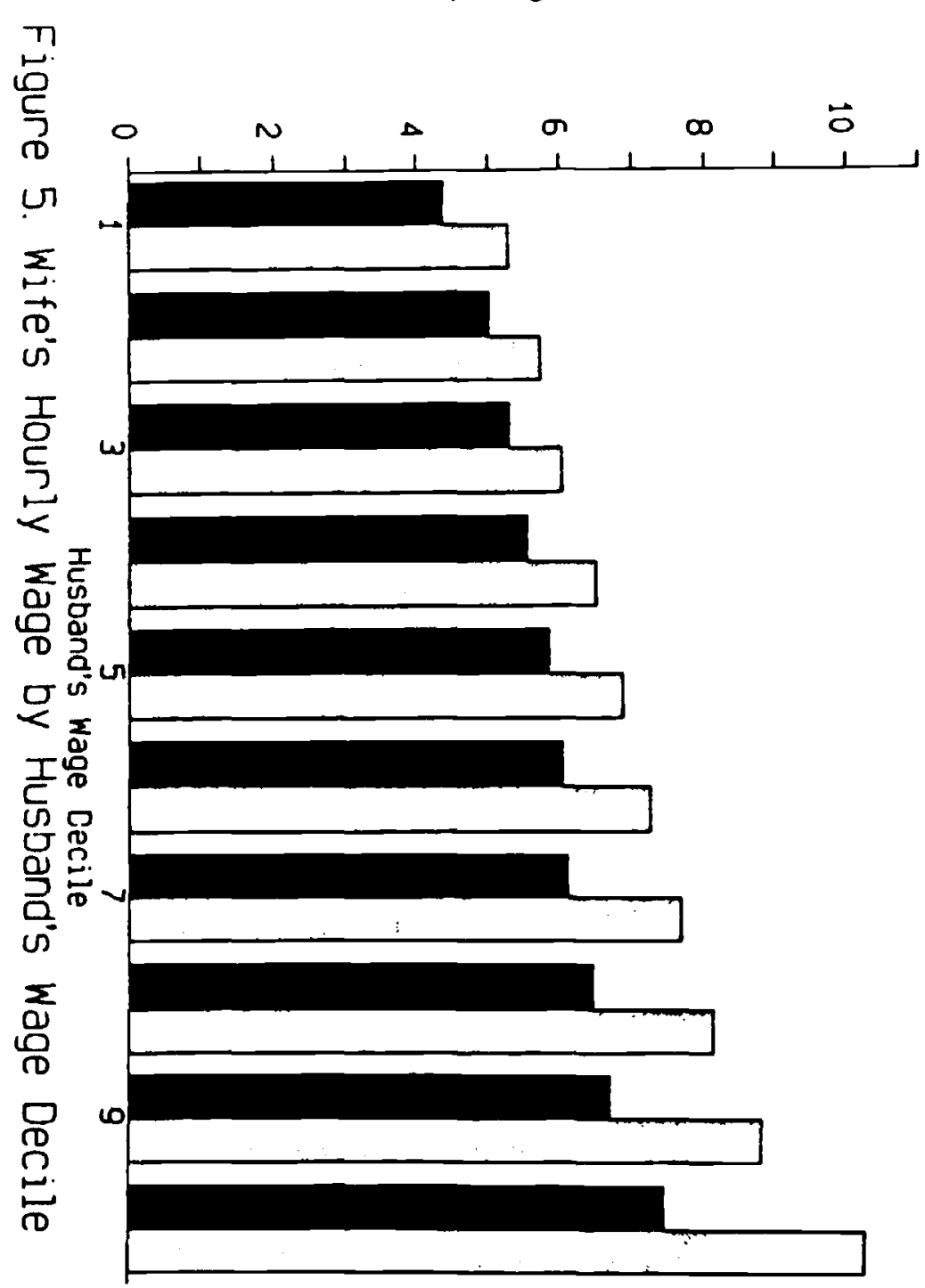




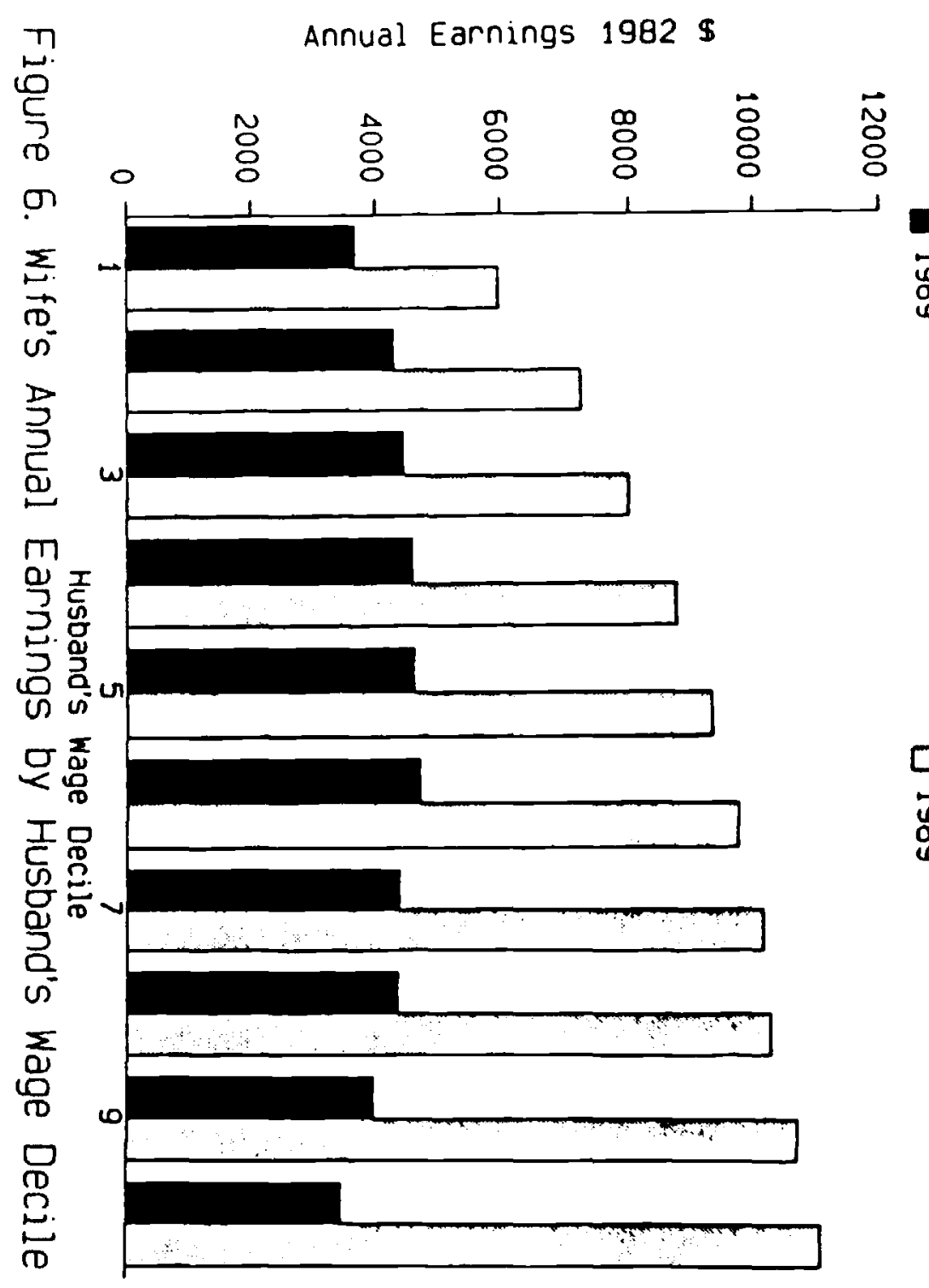




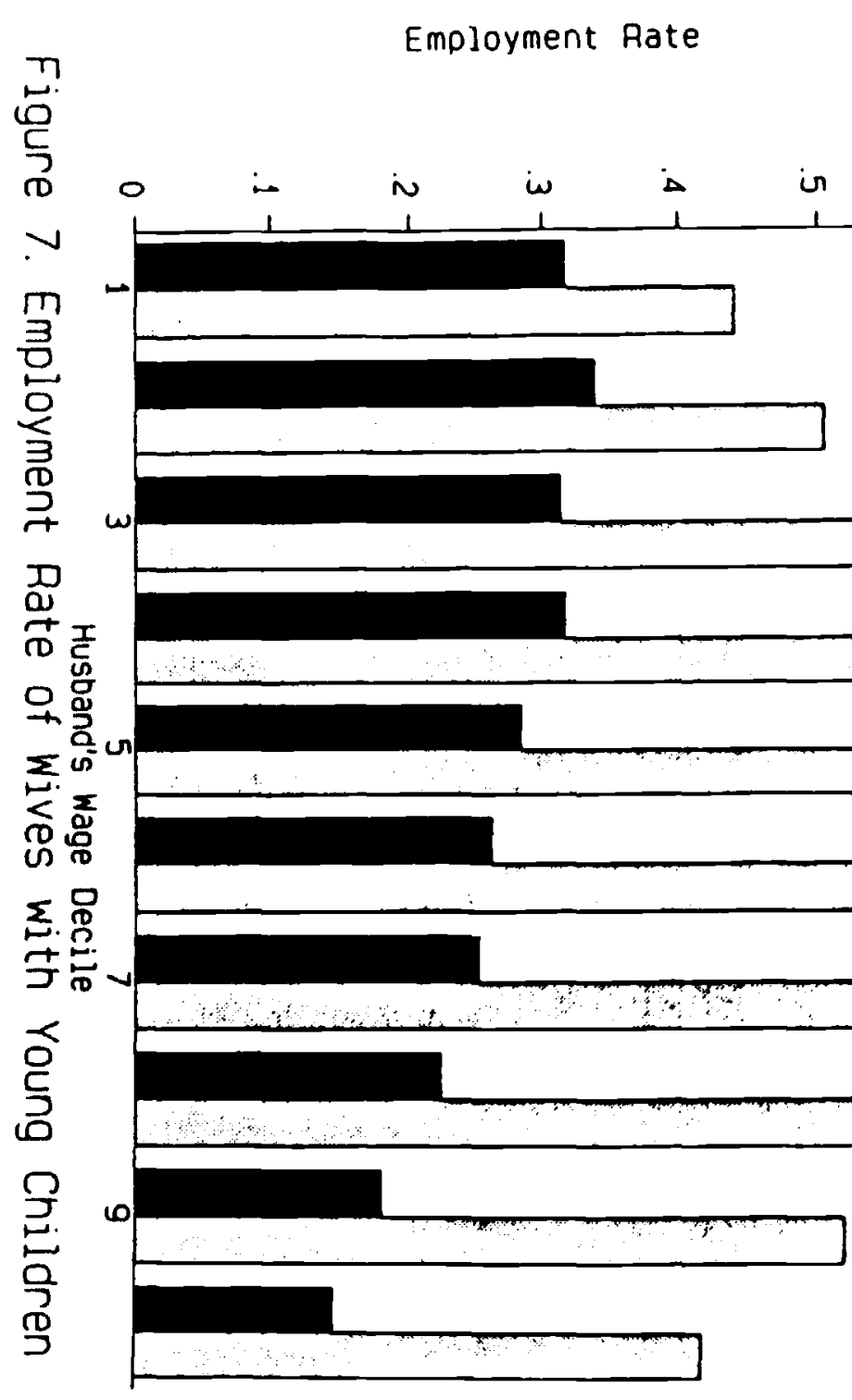




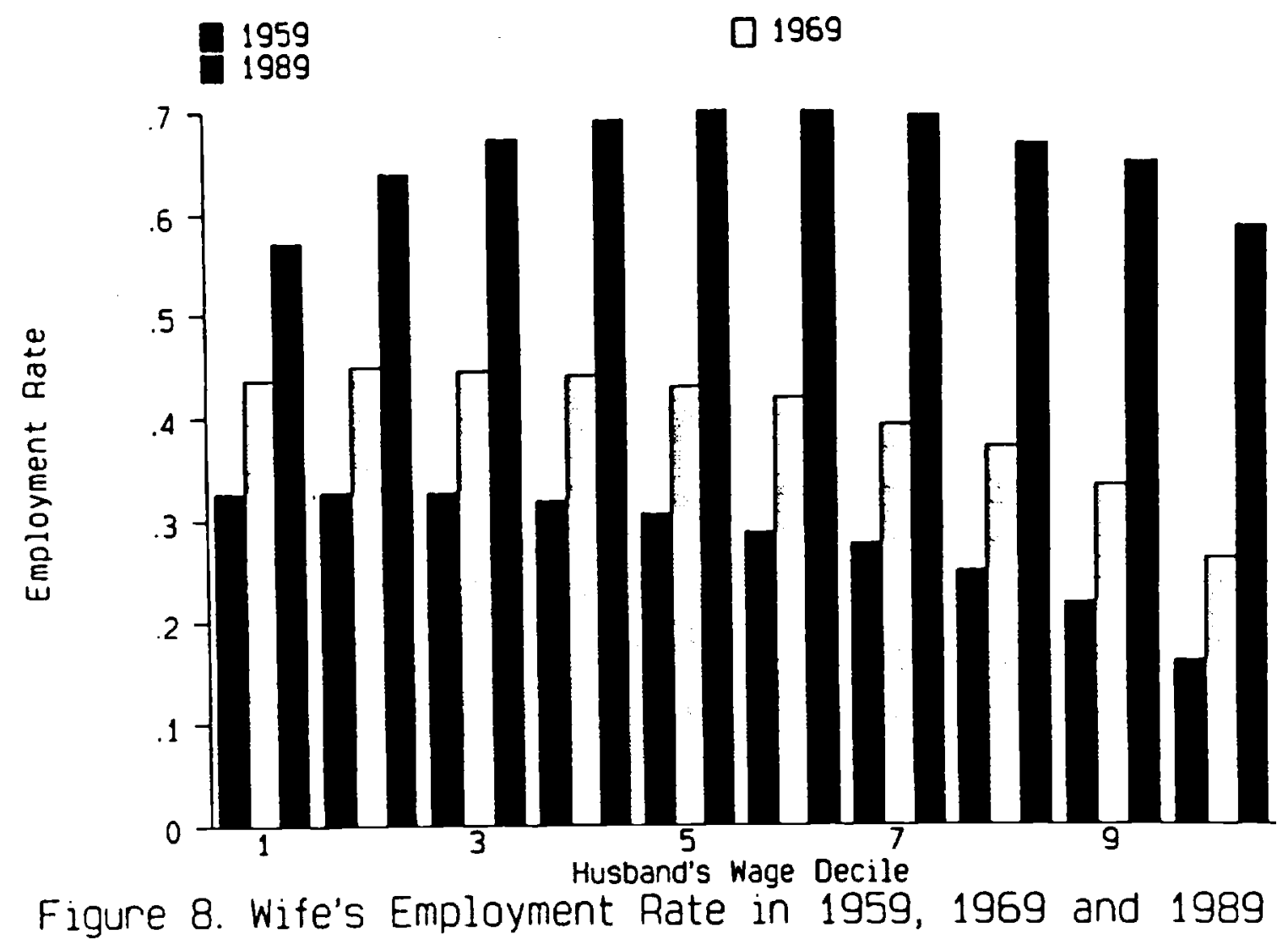

